Rev. Ter. Ocup. Univ. São Paulo, v. 21, n. 3, p. i, set./dez. 2010.

\title{
Editorial
}

\section{Fortalecer a Rede Nacional de Ensino em Terapia Ocupacional (RENETO): desafio necessário para a consolidação da área no campo do ensino e da pesquisa}

\section{Strengthen the National Network of Education in Occupational Therapy (RENETO): challenge needed to consolidate the area in teaching and researching}

Sob a chamada "Terapia Ocupacional e Docência: Articulação e Gestão nos Desafios e Conquistas", realizou-se, em Curitiba, na Universidade Federal do Paraná - UFPR, de 22 a 24 de setembro de 2010, o XII Encontro Nacional de Docentes de Terapia Ocupacional.

A partir da reflexão sobre os 50 anos da institucionalização do ensino de Terapia Ocupacional no Brasil, o encontro buscou discutir o momento atual, como aquele onde nos deparamos com um conjunto significativo de mudanças nos campos do ensino, pesquisa e extensão, provocados pelas atuais Políticas de Saúde e Educação, que muitas vezes assumem posturas contraditórias, a exemplo da redução da carga horária dos cursos da saúde, á revelia da posição de nossas entidades representativas e da luta pela melhoria da qualidade da formação dos profissionais da saúde.

Com extensa pauta de atividades, o encontro possibilitou a discussão da Docência em Terapia Ocupacional em múltiplas dimensões: o ensino no contexto das Políticas Públicas; experiências de formação e metodologias de ensino; o cenário de expansão, distribuição e manutenção de cursos de graduação; educação continuada; pós graduação e pesquisa . Além disso, houve continuidade no trabalho dos Grupos (GTs) já constituídos pela RENETO: educação continuada, pesquisa e pós-graduação strictu sensu; cursos de especialização; financiamento de pesquisas; parâmetro e avaliação dos cursos; periódicos de Terapia Ocupacional. Foi também criado um novo GT sobre residência multiprofissional em saúde.

Realizou-se ainda um encontro entre os coordenadores de cursos, mostra de experiências, oficina de metodologias ativas e uso de mapa conceitual.

A grande novidade, muito esperada por todos nós, foi o lançamento do site da RENETO, disponível em http://www.reneto. org.br/ que dá visibilidade á nossa associação e torna possível a comunicação e trocas entre todos os docentes, estudantes, cursos e interessados no ensino da área.

E esse é exatamente um dos pontos a serem trabalhados nos próximos dois anos de gestão da nova diretoria eleita no encontro: o aumento da comunicação e participação de todos. A RENETO precisa crescer e se fortalecer, pois tem desempenhado um importante papel na interlocução com as instituições governamentais envolvidas na gestão das Políticas de Educação e Saúde e com o conjunto das associações de ensino das profissões da área da saúde, reunidas no Fórum, Nacional de Educação das Profissões na área de Saúde (FNEPAS, acesso em http://www.fnepas.org.br), que se consolidou como um espaço privilegiado de interlocução e fortalecimento do ensino em saúde.

Para isso é necessário sensibilizar a todos os docentes para que ingressem na RENETO, participem do seu dia a dia e contribuam para que a área seja representada com compromisso, competência e representatividade. Temos que dar continuidade e construir novas pautas para aprimorar as Políticas nas quais atuamos, mas somos a menor categoria da área da saúde em número de profissionais e escolas, o que torna nossas lutas sempre mais difíceis de serem travadas.

A atual diretoria da RENETO lançou uma campanha de filiação que visa atingir todos os docentes e terapeutas ocupacionais dedicados ao ensino das atuais 63 escolas em funcionamento no Brasil. São: 3 no Centro Oeste, 11 no Nordeste, 6 no Norte, 33 no Sudeste e 9 no Sul e a expectativa é de que esse movimento chegue até todas elas em breve.

Assim contamos com todos vocês!

Junte-se a nós!

Filie-se à RENETO!!!

Elisabete Ferreira Mângia

Prof ${ }^{a} \operatorname{Dr}^{\mathrm{a}}$ do Departamento de Fisioterapia,

Fonoaudiologia e Terapia Ocupacional da USP

Editora da Revista de Terapia Ocupacional da USP 